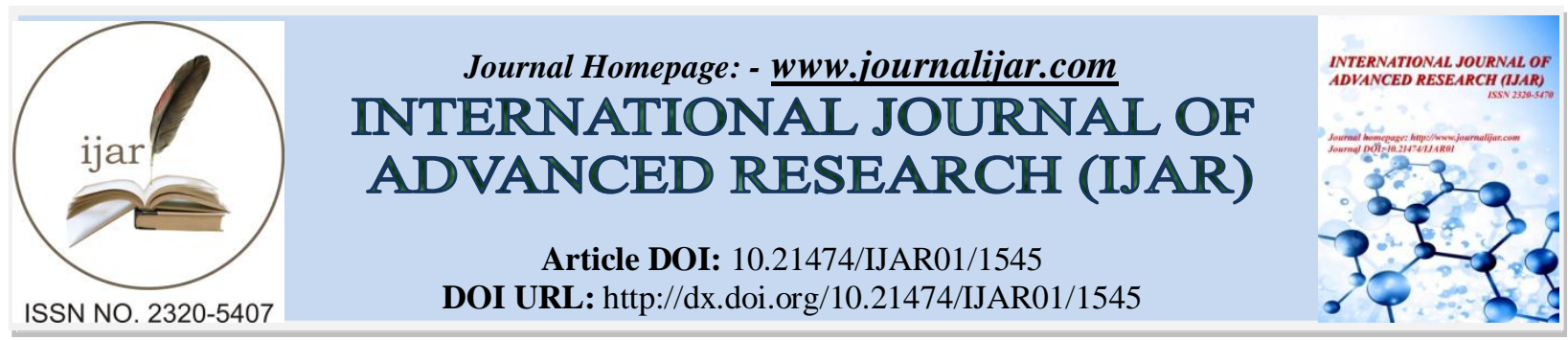

RESEARCH ARTICLE

\title{
EFFECT OF SALT AND WATER STRESS ON MORPHOLOGICAL AND PHYSIOLOGICAL PARAMETERS OF THREE VARIETIES OF TOMATO (LYCOPERSICON ESCULENTUM MILL.) CULTIVATED IN CÔTE D'IVOIRE.
}

\author{
Kouassi N'dri Jacob ${ }^{1 *}$, Ayolie Koutoua ${ }^{1}$, Seu Jonathan Gogbeu ${ }^{1}$, Soro Dognimeton ${ }^{1}$, Kouakou Tanoh Hilaire ${ }^{2}$ \\ and Kouadio Yatty Justin ${ }^{1}$.
}

1. Universite Jean Lorougnon Guede, Laboratoire de physiologie et pathologie vegetale, BP 150 Daloa, Cote d'Ivoir.e

2. Universite Nangui Abrogoua,UFR Sciences De La Nature, 02Bp 801 .Abidjan, Cote d'Ivoire.

\section{Manuscript Info}

Manuscript History

Received: 19 July 2016

Final Accepted: 22 August 2016

Published: September 2016

Key words:-

Water and salt stress, tomato, morphological, physiological and biochmique, Lycopersiconesculentum

\section{Abstract}

Tomato (Lycopersicon esculentum Mill.), Plant nutrition and economic interests, is often confronted with adverse environmental conditions including saline and water stress. These phenomena are forcing plants to significantly reduce their production. Thus, to address this issue, three varieties of tomato (Petomech, UC82B and Tropimech) were used to assess the impact of salt and water stress on morphological and physiological parameters. For this, tomato varieties were subjected to four concentrations of $\mathrm{NaCl}(0,2,4$ and $6 \mathrm{~g} / \mathrm{L})$ and five water treatment $(150,100,75,50$ and $25 \%$ of field capacity). The results show that $\mathrm{NaCl}$ decreases significantly the morphological parameters. However, this reduction is accentuated to $6 \mathrm{~g} / \mathrm{L}$. At the physiological level, $\mathrm{NaCl}$ has significantly reduced water content of the plant, chlorophyll a, b and total (t) and carotenoid content. Water stress reduced the morphological and physiological parameters.

Copy Right, IJAR, 2016,. All rights reserved.

\section{Introduction:-}

In Côte d'Ivoire, vegetable crops occupy a significant proportion (3.3\%) of all farm households (Soro et al., 2007). Among these, the tomato is the second largest fruit vegetable. Production in Ivory Coast is 32364 tons of tomato per year (Fondio et al., 2013). This production is low to meet the needs of the Ivorian people. The country still relies on imports from neighboring countries and other countries worldwide. Today, to meet this shortfall in production, the tomato is produced in all agricultural production areas of Ivory Coast (Soro et al., 2007). She took more and more momentum with diversification, the development of new varieties and processing of agricultural techniques. However, despite efforts to increase production, the cultivation of tomato is often confronted with many difficulties. Among these constraints, water is the main factor limiting plant productivity (Mouna et al., 2010). Scarce water conditions limit the expression of the production potential of varieties and make uncertain the hopes of farmers and consumers (Nana et al., 2009). This rainfall variability remains a constraint to agricultural development. Indeed, the culture of the tomato is often disrupted by drought as most tropical plants. Improving yields in arid tropical countries therefore requires the selection of varieties resistant to water stress (Mawuli et al., 2014). The water and salt stress must be considered an urgent problem, but as a phenomenon to be taken into account in food security and national development strategies (FAO, 2004). It is important to choose the varieties to offer to people taking into account

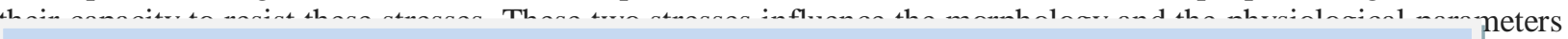

Corresponding Author:- Kouassi N'dri Jacob.

Address:- Universite Jean Lorougnon Guede, Laboratoire de physiologie et pathologie vegetale, BP 150 Daloa, Cote d'Ivoir.e 
of the tomato. It is in this light that three tomato varieties cultivated in Ivory Coast Daloa precisely, were selected to evaluate their resistance to water and salt stress. This work aims to study the behavior of three tomato varieties grown in the Ivory Coast under water and salt stress, through the evaluation of some morphological and physiological parameters

\section{Material and method:-}

\section{Study site:-}

The study was conducted in the University Jean Lorougnon Guede located in the town of Daloa in the west central Cote d'Ivoire. The geographical position is given by the following coordinates $6^{\circ} 53$ 'North $6^{\circ} 27^{\prime}$ Ouest. It is located in a forest area with temperatures from 21-31 ${ }^{\circ} \mathrm{C}$. It is located $141 \mathrm{~km}$ from the political capital Yamoussoukro and $383 \mathrm{~km}$ from Abidjan the economic capital. The climate of the region has four seasons: the long rains (April to mid-July), the short dry season (mid-July to mid-September), a small rainy season (mid-September to November) and large dry season (December to March).

\section{Experimental design:-}

Three local varieties of tomatoes (Lycopersicom esculentum) were used for this experiment. This is Petomech, UC82 and B Tropimech. The seeds were purchased in the market Daloa. These varieties are fixed with a specific growth and high production. Three ridges of $2 \mathrm{~m}$ length, height $20 \mathrm{Cm}$, width $1 \mathrm{~m}$ were used for the realization of the nursery for obtaining tomato plans. These logs were treated with two nematicide and fungicide. The transplanting was done in 4-liter pots containing the treated soil. The pots were perforated at the base and a thin layer of gravel was deposited before filling with soil. Pots, under glass, are deposited on a support. Some days (21) after seed germination, the more vigorous plants were planted in pots. This experiment was conducted in a greenhouse $3 \mathrm{~m}$ height. Salt solutions (2, 4 and 6 g.1-1) $\mathrm{NaCl}$ were used to water tomato selected plans. The witness watered by tap water. $\mathrm{NaCl}$ solutions and water were applied a week after planting tomato plants to the capture morphological data. As regards the water stress, the stress levels $(150 \%, 100 \%, 75 \%, 50 \%$ and $25 \%)$ relative to the capacity of the ground field were determined with an amount of $4.350 \mathrm{~kg}$ of ground culture. This amount of soil in the pots is the dry weight of the soil. The pots are then watered to saturation, while covering with aluminum foil to prevent evaporation of water. After 24 hours of rest, the pots are weighed again to get the weight of saturation. The difference between the saturation weight and dry weight of soil is the amount of water retained by the soil. This water is the ability to field soil content in the pots. Field capacity is calculated according to the method of Mouellef (2010):

\section{Data collection:-}

During this experience, some morphological and physiological parameters were evaluated after two months of treatment plants with different solutions of $\mathrm{NaCl}$ and water. The vegetative parameters such as the diameter of the rod, the height and size of the plant, number of roots and finally sheet by plant leaf area were evaluated. Regarding the physiological parameters, variables such as the water content of plants, relative water content of the sheet (ERR) and the determination of chlorophyll pigments and carotenoids were determined (Table 1).

Table 1:- Method of measurement of yield components of tomato varieties.

\begin{tabular}{|l|l|}
\hline $\begin{array}{l}\text { Yield and yield } \\
\text { components }\end{array}$ & Measurement approach and sample size per plot \\
\hline Morphological parameters performed on three plants per treatment (concentration) \\
\hline Stem diameter $(\mathrm{Cm})$ & $\begin{array}{l}\text { Measuring the circumference of the rods, made on three plants per treatment } \\
\text { (concentration) }\end{array}$ \\
\hline Plant height $(\mathrm{Cm})$ & $\begin{array}{l}\text { Measuring the distance separating the outermost sheet from the surface, } \\
\text { carried out on three plants per treatment (concentration) }\end{array}$ \\
\hline Scale plants $(\mathrm{Cm})$ & $\begin{array}{l}\text { Measuring the distance separating the two most extreme sheets, carried out } \\
\text { on three plants per treatment (concentration) }\end{array}$ \\
\hline Number of sheets & $\begin{array}{l}\text { Effective of all the leaves on three plants per treatment (concentration) } \\
\text { Foliar area }\left(\mathrm{Cm}{ }^{2}\right)\end{array}$ \\
\hline Number of roots & $\begin{array}{l}\text { Eeasuring the surface of the sheet, carried out on three plants per treatment } \\
\text { concentration) }\end{array}$ \\
\hline Root depth $(\mathrm{Cm})$ & $\begin{array}{l}\text { Measuring the length of the roots, carried on three plants per treatment } \\
\text { (concentration) }\end{array}$ \\
\hline
\end{tabular}




\begin{tabular}{|l|l|}
\hline \multicolumn{2}{|l|}{ Physiological parameters performed on three plants per treatment (concentration) } \\
\hline Relative water content of leaves $(\%)$ & $\begin{array}{l}\text { Difference between the fresh weight and dry weight of the leaves multiplied } \\
\text { by } 100\end{array}$ \\
\hline Water content of the plant TEP $(\mathrm{ml})$ & Difference between the fresh weight and dry weight of the whole plant \\
\hline Chlorophyll a $(\mu \mathrm{g} / \mathrm{mL})$ & Extraction and determination of chlorophyll pigments $(\mathrm{a})$ \\
\hline Chlorophyll $\mathrm{b}(\mu \mathrm{g} / \mathrm{mL})$ & Extraction and determination of chlorophyll pigments $(\mathrm{b})$ \\
\hline Chlorophyll Total $(\mu \mathrm{g} / \mathrm{mL})$ & Extraction and determination of total chlorophyll pigments $(\mathrm{t})$ \\
\hline Carotenoide $(\mu \mathrm{g} / \mathrm{mL})$ & Extraction and determination of carotenoids \\
\hline
\end{tabular}

\section{Statistical analysis of the data:-}

The one-way analysis of variance (Anova 1) was used to evaluate the effect of the concentration, variety and interaction through the comparison of the mean for each parameter. When a significant difference was observed $(\mathrm{P}$ $<0.05$ ) between the different factors studied for a given parameter, multiple comparisons were performed using the test Smallest Significant Difference (LSD). This test identified the factor that significantly induce this difference.

\section{Results and Discussion:-}

Effect of different concentrations of $\mathrm{NaCl}$ and field capacity on agro-morphological parameters of the three tomato varieties:-

Salinity has a significant influence on the development of leaves, number of roots and scale of the studied tomato plants. These parameters decrease with increasing $\mathrm{NaCl}$ concentration in the medium (Table 2). Thus, lower values for these parameters are obtained at concentrations of 4 and $6 \mathrm{~g} / \mathrm{L} \mathrm{NaCl}$. For cons, the highest values are observed in the control and the lowest concentration $(2 \mathrm{~g} / \mathrm{L})$. The results showed a complete difference in the depths of the roots for the four concentrations studied. Thus, when the $\mathrm{NaCl}$ concentration increases, the depth of the roots increases. The greatest value of the depth of the roots is obtained at the highest concentration $(6 \mathrm{~g} / \mathrm{L})$. In the parameters such as the diameter of the rod, the plant height and leaf area, a partial difference has been observed. This difference shows that these parameters decrease with increasing concentration of the medium. And the larger values are obtained with low concentrations of $\mathrm{NaCl}$. Statistical analysis showed a significant effect on all parameters studied. The agro-morphological parameters of tomato increased with increasing field capacity. Thus, the height of tomato plants, the stem diameter, leaf area, number of roots and leaves, the length of Raines and leaf specific weight increases with increasing field capacity (Table 3 ).

Table 2:- Effect of the various $\mathrm{NaCl}$ concentrations on the morphological parameters.

\begin{tabular}{|c|c|c|c|c|c|c|c|}
\hline & $\begin{array}{l}\text { plant } \\
\text { height } \\
(\mathrm{Cm})\end{array}$ & $\begin{array}{l}\text { stem } \\
\text { diameter }(\mathrm{Cm})\end{array}$ & $\begin{array}{l}\text { Foliar area } \\
\left(\mathrm{Cm}^{2}\right)\end{array}$ & $\begin{array}{l}\text { Number of } \\
\text { roots }\end{array}$ & $\begin{array}{l}\text { Number of } \\
\text { sheets }\end{array}$ & $\begin{array}{l}\text { Scale plants } \\
(\mathrm{Cm})\end{array}$ & $\begin{array}{l}\text { Root depth } \\
(\mathrm{Cm})\end{array}$ \\
\hline Témoin & $0,4 \pm 0,05^{\mathrm{a}}$ & $32,8 \pm 4,09^{a}$ & $34,7 \pm 3,3^{a}$ & $8,51 \pm 0,80^{a}$ & $48,1 \pm 5,04^{\mathrm{a}}$ & $175,6 \pm 22,59^{a}$ & $10,78 \pm 1,6^{\mathrm{d}}$ \\
\hline $2 \mathrm{~g} / \mathrm{L}$ & $0,3 \pm 0,04^{b}$ & $31,29 \pm 2,06^{\mathrm{ab}}$ & $32,3 \pm 3,11^{\mathrm{ab}}$ & $7,64 \pm 0,91^{\text {ab }}$ & $44,14 \pm 2,7^{\text {ab }}$ & $150,4 \pm 25,71$ ab & $12,54 \pm 3,11^{\mathrm{c}}$ \\
\hline $4 \mathrm{~g} / \mathrm{L}$ & $0,3 \pm 0,01^{\mathrm{bc}}$ & $29,36 \pm 2,53^{\text {ab }}$ & $30,0 \pm 3,2^{b}$ & $7,37 \pm 0,63^{b}$ & $41,4 \pm 5,67^{b}$ & $143,7 \pm 23,18^{b}$ & $13,25 \pm 1,33^{b}$ \\
\hline $6 \mathrm{~g} / \mathrm{L}$ & $0,3 \pm 0,02^{\mathrm{c}}$ & $28,6 \pm 2,70^{b}$ & $28,7 \pm 2,4^{b}$ & $7,19 \pm 1,11^{b}$ & $35,4 \pm 3,46^{\mathrm{c}}$ & $139,81 \pm 18,18^{b}$ & $14,3 \pm 1,37^{\mathrm{a}}$ \\
\hline $\mathrm{P}$ & $<0,001$ & 0,016 & $<0,001$ & 0,015 & $<0,001$ & 0,001 & 0,010 \\
\hline $\mathrm{F}$ & 14,717 & 4,140 & 15,565 & 4,244 & 11,228 & 6,726 & 4,642 \\
\hline
\end{tabular}

Mean values within column by parameter followed by the same superscripted letter were not significantly different at $p=0.05$ level, on the basis of the least significant difference test, salt solutions (2, 4 and 6 g.l-1)

Table 3:- Results of statistical tests assessing the impact of different levels of field capacity on agro-morphological parameters of the three tomato varieties studied.

\begin{tabular}{|l|l|l|l|l|l|l|l|}
\hline & $\begin{array}{l}\text { plant } \\
\text { height } \\
(\mathrm{Cm})\end{array}$ & $\begin{array}{l}\text { stem } \\
\text { diameter }(\mathrm{Cm})\end{array}$ & $\begin{array}{l}\text { Foliar area } \\
\left(\mathrm{Cm}^{2}\right)\end{array}$ & $\begin{array}{l}\text { Number of } \\
\text { roots } \\
\text { d }\end{array}$ & $\begin{array}{l}\text { Number of } \\
\text { sheets }\end{array}$ & $\begin{array}{l}\text { Scale plants } \\
(\mathrm{Cm})\end{array}$ & $\begin{array}{l}\text { Root } \\
\text { depth } \\
(\mathrm{Cm})\end{array}$ \\
\hline CC 25\% & $21,04 \pm 3,828^{\mathrm{d}}$ & $28,51 \pm 12,95^{\mathrm{c}}$ & $98,03 \pm 29,00^{\mathrm{b}}$ & $5,00 \pm 0,50^{\mathrm{d}}$ & $0,020 \pm 0,001^{\mathrm{b}}$ & $6,06 \pm 1,11^{\mathrm{c}}$ \\
\hline CC 50\% & $27,4 \pm 4,53^{\mathrm{c}}$ & $0,29 \pm 0,022^{\mathrm{c}}$ & $36,5 \pm 12,34^{\mathrm{bc}}$ & $130,3 \pm 30,61^{\mathrm{ab}}$ & $6,77 \pm 0,94^{\mathrm{c}}$ & $0,023 \pm 0,002^{\mathrm{ab}}$ & $6,84 \pm 1,27^{\mathrm{c}}$ \\
\hline CC 75\% & $\begin{array}{l}35,0 \pm 4,46 \\
\mathrm{~b}\end{array}$ & $0,35 \pm 0,029^{\mathrm{b}}$ & $45,66 \pm 7,42^{\mathrm{b}}$ & $168,56 \pm 26,51^{\mathrm{a}}$ & $8,92 \pm 0,82^{\mathrm{b}}$ & $0,023 \pm 0,002^{\mathrm{a}}$ & $8,91 \pm 1,13^{\mathrm{b}}$ \\
\hline CC100 & $37,2 \pm, 12^{\mathrm{b}}$ & $0,36 \pm 0,026^{\mathrm{ab}}$ & $48,48 \pm 9,05^{\mathrm{ab}}$ & $149,59 \pm 49,73^{\mathrm{a}}$ & $8,59 \pm 1,10^{\mathrm{b}}$ & $0,023 \pm 0,003^{\mathrm{a}}$ & $9,49 \pm 1,09^{\mathrm{b}}$ \\
\hline
\end{tabular}




\begin{tabular}{|l|l|l|l|l|l|l|l|}
\hline$\%$ & & & & & & & \\
\hline $\begin{array}{l}\mathrm{CC} 150 \\
\%\end{array}$ & $44,4 \pm 3,86^{\mathrm{a}}$ & $0,39 \pm 0,035^{\mathrm{a}}$ & $60,63 \pm 9,23^{\mathrm{a}}$ & $168,22 \pm 44,52^{\mathrm{a}}$ & $10,8 \pm 1,22^{\mathrm{a}}$ & $0,024 \pm 0,002^{\mathrm{a}}$ & $11,4 \pm 1,63^{\mathrm{a}}$ \\
\hline $\mathrm{F}$ & 55,179 & 44,67 & 17,671 & 15,702 & 74,846 & 5,468 & 29,488 \\
\hline $\mathrm{P}$ & $<0,001$ & $<0,001$ & $<0,001$ & $<0,001$ & $<0,001$ & 0,002 & $<0,001$ \\
\hline
\end{tabular}

Mean values within column by parameter followed by the same superscripted letter were not significantly different at $p=0.05$ level, on the basis of the least significant difference test Percentage water $(25 \%, 50 \%, 75 \%, 100 \%$ and $150 \%)$

Effect of different concentrations of $\mathrm{NaCl}$ and field capacity in fields on the physiological parameters of varieties of Tomato:-

The statistical analysis of these parameters showed a significant effect for the different concentrations of $\mathrm{NaCl}$ used. The results show that in the total chlorophyll and carotenoid, the highest values were obtained at the low concentration ( $2 \mathrm{~g} / \mathrm{L}$ ). Beyond $2 \mathrm{~g} / \mathrm{L}$, it was observed that the concentrations ( $4 \mathrm{~g} / \mathrm{L}$ and $6 \mathrm{~g} / \mathrm{L}$ ) have the same values at these two parameters. At the water content and chlorophyll (a), a decrease of the values was observed with the increase in salt concentration (table 4).

The evaluation of the effect of capacity to the field on the three varieties studied tomatoes covered six agrophysiological parameters which are: the water content of the plant, the relative water content of leaves, chlorophyll a $\mathrm{b}$ and total and the carotenoid content. Statistical analysis of the results showed a highly significant effect of field capacity on agro-physiological parameters tested. Parameters such as the water content of the plant, the relative water content of leaves, chlorophyll a, and total carotenoid content and increments with increasing field capacity. By cons, chlorophyll b decreases with increasing field capacity (table 5).

Table 4:- Results of statistical tests assessing the influence of salt concentration on the relative water content of the leaves and the water content of the tomato plants

\begin{tabular}{|l|l|l|l|l|l|l|}
\hline & TRE & TEP & $($ Chl a) & $($ Chl b $)$ & $($ ChlT $)$ & Caro \\
\hline Témoin & $66,58 \pm 7^{\mathrm{a}}$ & $10,14 \pm 0,8^{\mathrm{a}}$ & $11,2 \pm 2,2^{\mathrm{a}}$ & $6,29 \pm 2,3^{\mathrm{a}}$ & $17,77 \pm 4,3^{\mathrm{a}}$ & $9,923 \pm 2,6^{\mathrm{a}}$ \\
\hline $2 \mathrm{~g} / \mathrm{L}$ & $60,13 \pm 3,3^{\mathrm{a}}$ & $9,234 \pm 1,4^{\mathrm{a}}$ & $9,49 \pm 2,1^{\mathrm{a}}$ & $5,15 \pm 2,2^{\mathrm{a}}$ & $13,63 \pm 2,4^{\mathrm{b}}$ & $7,00 \pm 1,7^{\mathrm{b}}$ \\
\hline $4 \mathrm{~g} / \mathrm{L}$ & $47,2 \pm 5,8^{\mathrm{b}}$ & $8,375 \pm 0,5^{\mathrm{ab}}$ & $5,86 \pm 2,1^{\mathrm{b}}$ & $2,71 \pm 1,0^{\mathrm{b}}$ & $7,204 \pm 2,1^{\mathrm{c}}$ & $3,797 \pm 1,4^{\mathrm{c}}$ \\
\hline $6 \mathrm{~g} / \mathrm{L}$ & $40,57 \pm 7,0^{\mathrm{b}}$ & $7,756 \pm 1,1^{\mathrm{b}}$ & $2,96 \pm 0,9^{\mathrm{c}}$ & $1,88 \pm 1,3^{\mathrm{b}}$ & $4,48 \pm 1,2^{\mathrm{c}}$ & $2,233 \pm 0,7^{\mathrm{c}}$ \\
\hline $\mathrm{P}$ & $<0,001$ & $<0,001$ & $<0,001$ & $<0,001$ & $<0,001$ & $<0,001$ \\
\hline $\mathrm{F}$ & 36,162 & 8,830 & 15,565 & 9,894 & 40,517 & 30,885 \\
\hline
\end{tabular}

Mean values within column by parameter followed by the same superscripted letter were not significantly different at $p=0.05$ level, on the basis of the least significant difference test TRE : teneur relative en eau des feuilles; TEP : Teneur en eau de la plante; Chl a: Chlorophylle a; Chl b: Chlorophylle b; Chl t: Chlorophylle Totale ; Caro: Caroténoïde, salt solutions (2, 4 and 6 g.1-1)

Tableau 5:- Results of statistical tests assessing the impact of capacity levels in the field of agro-physiological parameters of three tomato varieties studied.

\begin{tabular}{|c|l|l|l|l|l|l|}
\hline & TRE & TEP & $($ Chl a $)$ & $($ Chl b) & $($ ChlT $)$ & Caro \\
\hline CC 25\% & $6,59 \pm 0,44^{\text {d }}$ & $33,67 \pm 8,95^{\mathrm{b}}$ & $0,68 \pm 0,16^{\mathrm{e}}$ & $0,50 \pm 0,18^{\mathrm{b}}$ & $1,19 \pm 0,32^{\mathrm{d}}$ & $0,17 \pm 0,05^{\mathrm{c}}$ \\
\hline CC $50 \%$ & $7,57 \pm 1,12^{\text {cd }}$ & $42,83 \pm 5,74^{\mathrm{b}}$ & $1,09 \pm 0,11^{\mathrm{d}}$ & $0,59 \pm 0,14^{\mathrm{b}}$ & $1,69 \pm 0,20^{\mathrm{c}}$ & $0,23 \pm 0,07^{\text {bc }}$ \\
\hline CC 75\% & $8,93 \pm 1,20^{\mathrm{bc}}$ & $54,42 \pm 11,49^{\mathrm{a}}$ & $1,40 \pm 0,10^{\mathrm{c}}$ & $0,50 \pm 0,15^{\mathrm{b}}$ & $1,97 \pm 0,36^{\mathrm{bc}}$ & $0,30 \pm 0,03^{\text {ab }}$ \\
\hline CC $100 \%$ & $10,10 \pm 1,50^{\mathrm{ab}}$ & $57,09 \pm 6,21^{\mathrm{a}}$ & $1,66 \pm 0,18^{\mathrm{b}}$ & $0,50 \pm 0,11^{\mathrm{b}}$ & $2,16 \pm 0,27^{\mathrm{ab}}$ & $0,34 \pm 0,06^{\mathrm{a}}$ \\
\hline CC $150 \%$ & $11,69 \pm 1,69^{\mathrm{a}}$ & $63,98 \pm 6,89^{\mathrm{a}}$ & $2,10 \pm 0,22^{\mathrm{a}}$ & $0,39 \pm 0,23^{\mathrm{a}}$ & $2,48 \pm 0,35^{\mathrm{a}}$ & $0,36 \pm 0,06^{\mathrm{a}}$ \\
\hline F & 18,911 & 19,801 & 81,434 & 3,641 & 27,203 & 34,202 \\
\hline P & $<0,001$ & $<0,001$ & $<0,001$ & 0,015 & $<0,001$ & $<0,001$ \\
\hline
\end{tabular}

Mean values within column by parameter followed by the same superscripted letter were not significantly different at $p=0.05$ level, on the basis of the least significant difference test TRE : teneur relative en eau des feuilles; TEP : Teneur en eau de la plante; Chl a: Chlorophylle a; Chl b: Chlorophylle b; Chl t: Chlorophylle Totale ; Caro: Caroténoïde, Percentage water $(25 \%, 50 \%, 75 \%, 100 \%$ and $150 \%)$ 


\section{Discussion:- \\ Effect of salt and water stress on agro-morphological parameters of the three tomato varieties:-}

The results of this study show a reduction morpho physiological parameters of the three varieties according to the increase of $\mathrm{NaCl}$ concentration. Similar results were obtained by Hassani (2008) on some chili varieties. Indeed this author in a study on pepper varieties, showed that high salt concentrations have a negative influence on the growth of the pepper varieties. The decrease in the growth of the vegetative observed in tomato plants can be explained by the fact that the $\mathrm{NaCl}$ acts by increasing the osmotic pressure of the medium. Which prevents the absorption of water by the root system. This lack of water absorption leads to the reduction in growth is a result of a decrease in the number of cell divisions (Benamar et al., 2009). The reduction of the growth may result from the increase in abscisic acid concentration in the aerial part or cytokinin concentration reduction. The reduction in growth is an adaptation strategy allowing the plant to reduce resource spending. These strategies, implemented to maintain homeostasis under conditions of stress, are consuming energy and resources they divert the expense of growth. According to our results, the salt stress causes a delay in plant growth. This results in a reduction in plant height. A decrease in leaf area that is accompanied by symptoms of stress such as foliar chlorosis and necrosis, leading to death of the leaves. This same symptom was observed by Chartzoulakis and Klapaki,(2000).

The water regime is a very important factor for the growth, development and yield of crops. Indeed, our results showed that under the effect of water stress, measured agro-morphological and physiological variables known throughout a significant reduction compared to the increase of the field capacity. Such results were obtained by Nana et al., (2010) on okra and Lalsaga et al., (2016) on cowpea. In view of these results on the parameters of the three tomato varieties studied, we will say that the slowdown in the growth rate has been accompanied by a reduction or stoppage of the height and diameter of stressed tomato plants. Indeed, a lack of water slows the key mechanism for growth, which are the auxèse. Regarding our results, the reduction was much more pronounced when water stress intervened (25\%) of the field capacity. At the three varieties of tomato, they all use the same strategy of tolerance to water stress for these two parameters (height and diameter). Our results are similar to those of Kara and Bellkhiri (2011) on wheat. The results also showed that 50\% more than field capacity, tomato plants growing in height and thickness significantly. The leaf surface of tomato plants receiving a severe water deficit was much smaller. The reduction was more pronounced at the peak stress level to $25 \%$. These results are consistent with those of Hanane (2008) on tomato. It confirms a reduction of leaf area of tomato plants under water stress. Indeed, this reduction in surface area is due to the reduction of cell division. The intensity of the imposed water stress caused a reduction in the number and length of roots. The irrigation level $150 \%$ has a large root but has no effect on the number of root. Water stress reduced the number sheet. These results confirm the observations of Amoumen et al. (2013) on durum wheat. A water intake above field capacity (CC) $150 \%$ promotes the formation of the leaves (10 leaves). The specific leaf weight of the tomato in the results obtained shows a slight decrease in the medium at the most severe water deficit of $25 \%$ of the CC.

Effect of salt and water stress on the physiological parameters of three tomato varieties:-

The physiological approach made in this study shows that chlorophyll a, b, and total carotenoid are negatively influenced by salt diet. Indeed, in our study, a decrease in the content of these pigments was observed with the increase in salt concentration. This is explained by the fact that a plant under stress reduced all metabolic activities that may induce excessive energy expenditure. Thus, reduction of the leaf surface involves a reduction in $\mathrm{CO} 2$ uptake and consequently a reduction of the photosynthetic activity. The similar results were observed by Baghizadeh explains that under saline regime, chlorophyll $\mathrm{a}, \mathrm{b}$, and total carotenoids were significantly reduced in two wheat varieties (Baghizadeh et al., 2014). Other studies have also revealed similar results to ours. Indeed, Abbas et al., (2013) found that excessive amounts of toxic ions in leaf tissue of tomato cultivars can act as agent degrading chlorophyll pigments. The study also revealed a decrease in the relative water content of the leaves and the water content in the tomato varieties. Indeed, increasing the $\mathrm{NaCl}$ concentration results in a decrease of tissue hydration increasing the concentration inside and therefore prevents the water outlet of the plant to the outside. The intensification of salt treatment is accompanied by a decrease in the level of hydration which still remains tolerable. Maintaining a relative high content of water, under salt stress, is a remarkable form of resistance.

The water content of the tomato plant was significantly reduced to a quarter (1/4) of the CC. Regarding the three varieties, they adopted these common behavior of tolerance to water stress on the water content. These results confirm those of Hanane (2008) on tomato. It was observed a slight increase in the water content in the medium at $150 \%$ DC. The decrease of the water content is considered a loss of turgor expanding cells (Durand, 2007). The relative water content of the leaves of the tomato fell sharply to $25 \%$ of the CC. Our results showed that water intake 
by $50 \%$ over $150 \%$ of field capacity has no effect on the relative water content of leaves of tomato. The fall of the leaf relative water content is due to the loss of power accumulation of metabolites and osmotic adjustment for the maintenance of cell turgor and physiological activities (Bayoumi et al., 2008). The pigment chlorophyll content of leaves of tomato varieties is significantly affected by the lack of water in the soil. This pigment chlorophyll content decreases correspondingly over the degree of water deficit. The reduction in total chlorophyll is more pronounced in treatment $25 \%$ of the CC. As chlorophylls, the carotenoid content of tomato leaves decreases when the amount of water is reduced relative to the field capacity. The reduction is most prominent at $25 \%$ of the CC.

\section{Conclusion:-}

Salt stress exerts in three varieties of tomatoes a depressive effect on all morphological parameters, physiological and biochemical. The results of this study showed a decrease in agro-morphological and physiological parameters when water deficit is severe (50\% and 25). By cons, it was noted a strong accumulation of proline content and increased enzyme activity in the strongest water restriction levels (50\% and 25\%).

\section{References:-}

1. Abbas, T., Pervez, M.A., Ayyub C.M., Ahmad, R. (2013). Assessment of Morphological, Antioxidant, Biochemical and Ionic Responses of Salt Tolerant and Salt Sensitive Okra (Abelmoschus esculentus L.) under Saline Regime," Pak. j. life social. Science 11: 147-153.

2. Baghizadeh, A., Salarizadeh, M.R., Abaasi, F. (2014). Effects of Salicylic acid on some physiological and biochemical parameters of Brassica napus L.(Canola) under salt stress," International Journal of Agri Science, 4: 147-152.

3. Hassani, A., Dellal, A., Belkhodja., Kaid- Harche M. (2008). Effet de la Salinité sur l'eau et certains osmolytes chez l'orge (HordeumVulgare L.). European Journal of scientific Research 23: 61-69.

4. Kara, K., Brinis, L. (2012). Réponse Physiologique au Stress Hydrique de Variétés de Blé Tendre (Triticum Aestivum L.) Cultivées en Algérie, European Journal of Scientific Research, 81: 524-532.

5. Soro, S., Doumbouya, M., Koné, D. (2008). Potentiel infectieux des sols de cultures de tomate (Lycopersicon esculentum Mill.) sous abri et incidence de l'âge de repiquage sur la vigueur des plants vis-à-vis de Pythium sp. à Songon-Dabou en Côte d'Ivoire. Tropicultura, 26, (3): 173-178

6. Amoumen, S., Benhebireche, N. (2013) - Contribution à l'étude de la tolerance au deficit hydrique du blé dur (Triticum durum Desf). Mémoire de Master Academique en Science de la nature et de la vie (spécialité Biotechnologie Végétale), Département des Sciences dela nature et de la vie, Université Kasdi Merbah Ouargla, $60 \mathrm{p}$.

7. Bayoumi, T.Y., Manal, H., Metwali, E.M. (2008) - Application of physiological and biochemical indices as a screening technique for drought tolerance in wheat genotypes. African Journal of Biotechnology, 14: 23412352.

8. Durand, J.L. (2007) - Les effets du déficit hydrique sur la plante, aspects physiologiques. Fourrages, 190: 181195.

9. FAO. (2004) - Utilisation des phosphates naturels pour une agriculture durable. Bulletin FAO engrais et nutrition végétale, $45 \mathrm{p}$.

10. Fondio L., Djidji A.H., N'gbesso M.P.F., Kone D. (2013) - Evaluation de neuf variétés de tomate (Solanum Lycopersicum L.) par rapport au flétrissement bactérien et à la productivité dans le Sud de la Côte d'Ivoire. International. Journal of. Biological and Chemical Sciences, 7(3): 1078-1086.

11. Hanane T. (2008) - Efficience de l'utilisation de l'eau d'irrigation chez la tomate par la technique de PRD (Partial Rootzone Drying) et étude des mécanismes physiologiques et biochimiques impliqués. Thèse de Doctorat (spécialité Biotechnologie Végétale), UFR Biologie et santé, Université Cadi Ayyad, 132p.

12. Kara Y., Bellkhiri C.E. (2011) - Etude des caractères d'adaptation au déficit hydrique de quelques variétés de blé dur et d'espèces sauvages apparentées: intérêt potentiel de ces variétés pour l'amélioration de la production. Courrier du Savoir, N¹1, pp.119-126.

13. Lalsaga, A.J.W., Nana R., Sawadogo M., Sawadogo N., Kiebre M., Drabo I. (2016) - Evaluation de dix (10) génotypes de niébé [Vigna unguiculata (L.) walp.] par rapport à leur tolérance au stress hydrique. International Journal of Innovation and Applied Studies, 14: 1005-1014.

14. Mawuli, A., Ayayi A., Komi O., Abalo-Esso M. (2014) - Etude de l'influence du stress hydrique sur deux lignées de niébé. European Scientific Journal, 10, (30): 1857 - 1881 
15. Mouellef, A. (2010) - Caractères physiologiques et biochimiques de tolérance du blé dur (Triticum durum Desf) au stress hydrique. Mémoire de magistère en Biotechnologies Végétales, Département de Biologie Végétale et Ecologique, Université Mentourie, Constantine, $77 \mathrm{p}$.

16. Mouna, E., Said M., Mounsif B., Nasserelhaq N. (2010) - Effet du stress hydrique sur la répartition ionique dans les feuilles et les racines du blé dur (Triticum Durum). Nature \& Technologie, 5: 66-71.

17. Nana, R., Tamini Z., Sawadogo M. (2009) - Effets d'un stress hydrique intervenu pendant le stade végétatif et la phase de floraison chez le gombo. International Journal of Biological and Chemical Sciences, 3 (5): 1161-1170.

18. Nana, R., Tamini Z., Sawadogo M., Some P.P.(2010) - Etude morphologique comparative de cinq variétés de gombo [abelmoschus esculentus (L.) moench] soumises a un stress hydrique. Journal des Sciences, 10, (3): 28 38.

19. Soro, S., Doumbia M., Dao D., Tschannen A., Girardin O. (2007) - Performance de six cultivars de tomate (Lycopersicon esculentum Mill.) contre la jaunisse en cuillère des feuilles, le flétrissement bactérien et les nématodes à galles. Sciences et Nature, 4(2): 123-130. 